\title{
MENGENANGKAN DEKRIT PERFECTAE CARITATIS TENTANG PEMBAHARUAN DAN PENYESUAIAN HIDUP RELIGIUS
}

\author{
Raidin Sinaga*
}

\begin{abstract}
Abstrak
Yesus Kristus adalah pusat sejarah keselamatan, Dia juga puncaknya. Gereja berada dalam fase "inter tempora", antara kedatangan pertama (Parousia I) dan yang kedua (Parousia II). Gereja "ada dalam dan bersama dunia", tetapi sekaligus "tidak berasal dari" dunia. Keberadaan Gereja dalam sejarah manusia dan dunia, yang juga diyakini merupakan bagian dari sejarah keselamatan, menyadarkan Gereja akan "keduniawian"-nya. Kesadaran ini mendorong Gereja untuk mengadakan pertobatan dan pembaharuan diri. Dalam alur pemikiran ini Gereja dilihat bukan lagi sesuatu yang sempurna dan tetap mampu menjadi jawaban untuk manusia dalam setiap zaman. Sebaliknya, Gereja harus selalu memperbaharui diri supaya tetap aktual dan efektif dalam mewahyukan Allah dan menghadirkan Kerajaan-Nya di tengah manusia dan dunia yang menyejarah dan selalu mengalami perubahan. Gereja ada untuk misi perutusan, yakni demi keselamatan manusia dan dunia. Dari terminologi Yunani yang digunakan untuk menggambarkan Gereja, fungsi utama atau untuk apa Gereja ada menjadi sangat jelas. Kata yang dipakai ialah ekklesia (ek-kaleo) yang berarti "dipanggil keluar untuk berkumpul". Panggilan ini bertujuan bukan demi Gereja sendiri tetapi demi misi perutusan. Gereja ada bukan untuk dirinya sendiri tetapi demi pelayanan umat manusia dan untuk membawa kabar keselamatan bagi seluruh dunia.
\end{abstract}

Kata-kata Kunci: Yesus Kristus, Gereja, manusia, dunia, misi, perutusan,inter tempora, keselamatan.

\section{Pengantar}

Hari Studi Imam dalam rangka Tahun Hidup Bakti (30 November 2014 - 02 Februari 2016), adalah konteks dan alasan penulisan artikel ini. Dengan sengaja diberi judul "mengenang" dengan tujuan liturgi-teologis, mengingatkan kita akan kata anamnesis (Yunani) dalam tradisi biblis-Yahudi. Kata ini tidak dimengerti hanya sekedar mengingat-ingat secara intellektual atau peringatan orang mati, tetapi 
menurut arti kata Ibrani zikkaron yang menunjuk kesatuan antara kenangan dan tindakan. Hal ini misalnya jelas dalam Kitab Kejadian: “... Allah mengingat Nuh ... dan Allah membuat angin menghembus melalui bumi..." (8:1), “... Allah ingat kepada Abraham, lalu dikeluarkan-Nyalah Lot..." (19:29), "Lalu ingatlah Allah..., mendengarkan permohonannya..." (30:22). Jadi dengan "mengenang" di sini dimaksudkan "menghadirkan apa yang dikenangkan itu sedemikian rupa sehingga apa yang dikenangkan itu kini betul-betul ada, hadir, berdaya, dan bertindak". ${ }^{1}$ Dekrit Perfectae caritatis akan dihadirkan dengan "roh"-nya. Hal ini sangat ditekankan oleh TimTHB KAM dalam permohonan kepada pemateri dan dalam tujuan pertemuan. Para peserta tentu diharapkan akan menindaklanjuti apa yang disepakati bersama dalam tindakan dan dalam hidup. Dengan demikian, THB ini akan menjadi tahun berahmat (khairos), bukan tahun biasa yang rutin (khronos).

Dekrit Perfectae caritatis, sebagai salah satu dari 16 dokumen Konsili Vatikan II, ${ }^{2}$ tidak mungkin dipahami dengan baik kalau "roh atau semangat" yang melatarbelakangi pembaharuan dari Konsili tersebut tidak disadari dan dimengerti dengan tepat. Untuk tujuan ini, akan lebih dulu diterangkan "roh dan semangat" pembaharuan Konsili Vatikan II, supaya pembaharuan dan penyesuaian yang diungkapkan dalam dekrit Perfectae caritatis, yang akan diterangkan kemudian, bisa dimengerti dan diterima.

1 E. Martasudjita, Ekaristi: Tinjauan Teologis, Liturgis, dan Pastoral (Yogyakarta: Kanisius, 2005), hlm. 233.

2 Terdiri dari 4 Konstitusi (Konstitusi dogmatis Dei Verbum tentang Wahyu Ilahi; Konstitusi dogmatis Lumen gentium tentang Gereja; Konstitusi Sacrosanctum concilium tentang Liturgi Suci; dan Konstitusi Pastoral Gaudium et spes tentang Gereja dalam Dunia Modern), 9 Dekrit (Dekrit Inter mirifica tentang Upaya-upaya Komunikasi Sosial; Dekrit Orientalium ecclesiam tentang Gerejagereja Timur Katolik; Dekrit Unitatis Redintegratio tentang Ekumenisme; Dekrit Christus Dominus tentang Tugas Pastoral para Uskup dalam Gereja; Dekrit Perfectae caritatis tentang Pembaharuan dan Penyesuaian Hidup Religius; Dekrit Optatam Totius tentang Pembinaan Imam; Dekrit Apostolicam actuositatem tentang Kerasulan Awam; Dekrit Ad gentes tentang Kegiatan Misioner Gereja; Dekrit Presbyterorum ordinis tentang Pelayanan dan Kehidupan Para Imam), dan 3 Pernyataan (Pernyataan Gravissimum educationis tentang Pendidikan Kristen; Pernyataan Nostra aetate tentang Hubungan Gereja dengan Agama-agama Bukan Kristen; Pernyataan Dignitatis humanae tentang Kebebasan Beragama). 
Raidin Sinaga, Mengenang Dekrit Perfectae Caritatis ...

\section{Roh Pembaharuan Konsili Vatikan II}

Dalam undangan untuk mengadakan konsili ${ }^{3}$ Paus Yohanes XXIII mengungkapkan harapan beliau untuk konsili tersebut: merupakan ulangan Pentekosta bagi umat kristen. Beliau mengharapkan turunnya Roh Kudus yakni Roh Kebenaran yang akan memimpin Gereja "ke dalam seluruh kebenaran" (Yoh. 16:13); Roh Penolong yang akan mendampingi Gereja selama-lamanya (Yoh. 14:16), dan menjadikan setiap orang kristen "saksi-Ku di Yerusalem dan di seluruh Yudea dan Samaria dan sampai ke ujung bumi" (Kis. 1:8). Roh Kudus ini diharapkan akan membimbing Gereja untuk memperbaharui diri supaya sungguh-sungguh mampu mewartakan dan menghadirkan Kabar Gembira dan kesatuan di tengah situasi dunia yang sedang bergolak, mencemaskan, dan kurang memberi harapan akan damai dan keadilan. ${ }^{4}$ Dengan pembaharuan diri atas bimbingan Roh Kudus, Gereja akan mampu menghadirkan Kerajaan Allah di tengah dunia dan membimbing orang-orang dari segala suku, bangsa dan bahasa untuk masuk dan ambil bagian dalam Kerajaan tersebut.

${ }^{3}$ Undangan tersebut dibuat oleh Paus Yohanes XXIII dalam bentuk Konstitusi Apostolik dengan nama Humanae Salutis, dan dikeluarkan atau disebarkan pada Hari Raya Natal, tanggal 25 Desember 1961.

4 "According to Pope John, it was towards the end of 1958, shortly after assuming the papacy, that he engaged the late Cardinal Tardini in a troubled conversation regarding the state of the world and the Church's role in it. In a time of agitation and anxiety, amidst apparently hopeless clamorings for peace and justice, he asked his Secretary of State what might be done to give the world an example of peace and concord between men and an occasion for new hope, when suddenly there sprang to his own lips the words, 'A Council!'" [Xavier Rynne, Vatican Council II (New York: Farrar, Straus and Giroux, 1968), hlm. 3].

5 Ungkapan Ecclesia semper reformanda kadang dianggap sangat protestan (Reformator), padahal ungkapan itu berasal dari tradisi katolik yang sudah sangat tua [Lih. Johannes Feiner, "Commentary on the Decree", dalam Herbert Vorgrimler (ed.), Commentary on the Documents of Vatican II, vol II, transl. By William Glen-Doepel, et. al. (New York: Crossroad Publishing Company, 1989), hlm. 95-96].

Dalam dokumen Konsili Vatikan II, tidak dibedakan reformasi dari renovasi. Reformasi bertujuan untuk mengembalikan pada bentuk awal yang sudah "rusak" oleh dosa dan kelemahan manusiawi; sedangkan renovasi dilihat sebagai usaha pembaharuan dalam konteks lebih luas dan mendalam, menyangkut seluruh kehidupan kekristenan berdasarkan semangat injili (Herbert Vorgrimler (ed.), Commentary on the Documents of Vatican II, vol II, ... hlm. 95). 
Ecclesia semper Reformanda - aggiornamento

Kehadiran pengamat dari Gereja Protestan, teristimewa Oscar Cullmann, memberi sumbangan sangat berharga untuk orientasi dan perspektip Konsili Vatikan II: "penemuan sejarah keselamatan". Keselamatan sudah terjadi dalam sejarah dunia dan manusia, tetapi belum sempurna. Hal itu akan terjadi pada Kedatangan Kristus untuk yang kedua kalinya (Parousia II). Hal ini berbeda dengan pandangan yang umum diterima sebelum Vatikan II yang menganggap keselamatan itu baru terwujud nanti pada akhir zaman.

Yesus Kristus adalah pusat sejarah keselamatan, Dia juga puncaknya. Gereja berada dalam fase "inter tempora", antara kedatangan pertama (Parousia I) dan yang kedua (Parousia II). Gereja "ada dalam dan bersama dunia", tetapi sekaligus "tidak berasal dari" dunia. ${ }^{7}$ Keberadaan Gereja dalam sejarah manusia dan dunia, yang juga diyakini merupakan bagian dari sejarah keselamatan, menyadarkan Gereja akan "keduniawian"-nya. Kesadaran ini mendorong Gereja untuk mengadakan pertobatan dan pembaharuan diri. Dalam alur pemikiran ini Gereja dilihat bukan lagi sesuatu yang sempurna dan tetap mampu menjadi jawaban untuk manusia dalam setiap zaman. Sebaliknya, Gereja harus selalu memperbaharui diri supaya tetap aktual dan efektif dalam mewahyukan Allah dan menghadirkan Kerajaan-Nya di tengah manusia dan dunia yang menyejarah dan selalu mengalami perubahan. Dengan kata lain, pembaharuan ini, menurut dekrit Unitatis redintegratio tentang ekumenisme, selalu dituntut oleh kenyataan Gereja "sebagai suatu lembaga manusiawi dan duniawi". 8

6 Ungkapan Ecclesia semper reformanda kadang dianggap sangat protestan (Reformator), padahal ungkapan itu berasal dari tradisi katolik yang sudah sangat tua [Lih. Johannes Feiner, "Commentary on the Decree", dalam Herbert Vorgrimler (ed.), Commentary on the Documents of Vatican II, vol II, transl. By William Glen-Doepel, et. al. (New York: Crossroad Publishing Company, 1989), hlm. 95-96].

Dalam dokumen Konsili Vatikan II, tidak dibedakan reformasi dari renovasi. Reformasi bertujuan untuk mengembalikan pada bentuk awal yang sudah "rusak" oleh dosa dan kelemahan manusiawi; sedangkan renovasi dilihat sebagai usaha pembaharuan dalam konteks lebih luas dan mendalam, menyangkut seluruh kehidupan kekristenan berdasarkan semangat injili (Herbert Vorgrimler (ed.), Commentary on the Documents of Vatican II, vol II, ... hlm. 95).

7 Bdk. LG, 8.

$8 \mathrm{UR}, 6$. 
Raidin Sinaga, Mengenang Dekrit Perfectae Caritatis ...

Dalam bahasa yang lebih populer untuk Konsili Vatikan II, pembaharuan ini disebut oleh penggagasnya sebagai sebuah aggiornamento atau pengaktualan (a bringing up to date). ${ }^{9}$ Dalam aaggiornamento ini Gereja harus terbuka terhadap tuntutan dunia yang bisa dikenal dengan membaca tanda-tanda zaman (reading the signs of the times). ${ }^{10}$ Tanda-tanda zaman ini dimengerti oleh Paus Yohanes XXIII tidak dalam arti eskatologis biblis tetapi dalam arti historis konkrit, sebagai petunjuk untuk pergerakan-pergerakan utama dalam sejarah yang dengannya Allah mengungkapkan kehendak-Nya untuk Gereja di dunia saat ini dan di masa mendatang. ${ }^{11}$ Untuk sampai pada tujuan tersebut maka tanda-tanda zaman harus ditafsirkan "dalam cahaya Injil".12 Oleh karena itu, aggiornamento tidak bisa dimengerti melulu hanya sebagai tuntutan "modernisasi" dalam Gereja. ${ }^{13}$

Paus Yohanes XXIII sadar akan mendesaknya aggiornamento, maka beliau mengharapkan sebuah konsili di mana Gereja harus

${ }^{9}$ Xavier Rynne, Vatican Council..., hlm. 8. Lode L. Wostyn, professor teologi di Maryhill School of Theology, merumuskan aggiornamento sebagai "a renewal within the Church and the opening of windows for a fresh dialogue with the world" [Lode L. Wostyn, Doing Ecclesiology. Church and Mission Today (Quezon City Philippines: Claretian Publications, 1990), hlm. 44].

10 Sebelum Konsili Vatikan II, ungkapan tanda-tanda zaman sangat jarang muncul dan digunakan dalam dokumen-dokumen Gereja. Paus Yohanes XXIII adalah paus pertama yang menaruh perhatian khusus untuk itu, dan justru dia lakukan itu dalam bulla Humanae salutis dengan mana beliau mengundang untuk sebuah konsili: "Indeed, we make ours the recommendations of Jesus that one should know how to distinguish the 'signs of the times' (Mat 16:3), and we seem to see now, in the midst of so much darkness, a few indications which auger well for the fate of the Church and of humanity" (Humanae salutis, no. 54; dikutip dari Raidin R. Sinaga, Church and Mission within A Polycentric World. A Critical Study on Walbert Boehlmann's Missionary Thought (Rome: PUG, 2000), hlm. 68 (Unpublished Dissertation)

${ }_{11}$ Raidin R. Sinaga, Church and Mission..., hlm. 68-69. Konsili menyebut beberapa contoh dari tanda-tanda zaman tersebut: "begitu mendalam merasakan kesatuannya serta saling tergantungnya semua orang dalam solidaritas", "manusia mempunyai rasa kebebasan setajam seperti sekarang ini" (GS, 4); "manusia zaman sekarang menghendaki untuk dengan bebas dapat mengakui agamanya baik secara perorangan maupun di muka umum" (DH, 15); "semangat setiakawan antar semua bangsa, yang makin meluas dan tak terelakkan" (AA, 14); dll.

$12 \mathrm{GS}, 4$.

${ }^{13}$ Johannes Feiner, "Commentary...", hlm. 96. 
mengevaluasi diri dan pelaksanaan misinya. ${ }^{14}$ Dengan kata lain, perubahan yang diharapkan harus menyangkut keberadaan Gereja (being) dan bagaimana Gereja bersikap dan mewartakan Injil (doing) kepada seluruh dunia. ${ }^{15}$ Artinya, pembaharuan itu harus terjadi dalam dua arah: "ke dalam" (ad intra) dan "ke luar" (ad extra). Para bapak konsili juga mengikuti arah ini. Pembaharauan "ke dalam" (ad intra) kita mengerti ketika mereka mengatakan bahwa Gereja pertama-tama harus melaksanakan "pembaharuan batin" dengan tobat dan pemurnian diri. ${ }^{16}$ Sementara pembaharuan "ke luar" (ad extra) dinyatakan dalam seluruh dokumen yang menjelaskan tentang misi dan hubungan Gereja dengan dunia dan luar dirinnya ${ }^{17}$, dan secara istimewa dalam Konstitusi Pastoral Gaudium et spes tentang Gereja dalam Dunia Modern.

Tahun 1968, tiga tahun setelah penutupan Konsili Vatikan II, diterbitkan buku Yves Congar tentang pembaharuan yang benar dan salah dalam Gereja. Menurut Congar, pembaharuan dibutuhkan dalam

14 Dokumen Konsili Vatikan II, diterjemahkan oleh R. Hardawiryana (Jakarta: Dokumentasi dan Penerangan KWI, 1993), hlm. vi.

${ }^{15}$ Lih. Richard R. Sinaga, Communion of Communities: Cara Baru Hidup Menggereja di Asia (Nagahuta-Pematangsiantar: Rumah Pembinaan Fransisikan, 2008), hlm. 6. Bahan ini diberikan dalam Sinode V KAM, tanggal $01 \mathrm{~s} / \mathrm{d} 05$ Desember 2008, di Nagahuta-Pematangsiantar dengan tema Habitus BaruHidup Menggereja: Pengembangan Pastoral Berdasarkan Panca Tugas Gereja Secara Kontekstual.

16 AG, 35 dan LG, 8 dan 12. Pembaharuan "ke dalam" (ad intra) dinyatakan terutama dalam Konstitusi Dogmatis Lumen gentium tentang Gereja. Hal ini juga menjadi arah utama Konstitusi (Konstitusi dogmatis Dei Verbum tentang Wahyu Ilahi; Konstitusi Sacrosanctum concilium tentang Liturgi Suci; Dekrit Orientalium ecclesiam tentang Gereja-gereja Timur Katolik; Dekrit Christus Dominus tentang Tugas Pastoral para Uskup dalam Gereja; Dekrit Perfectae caritatis tentang Pembaharuan dan Penyesuaian Hidup Religius; Dekrit Optatam Totius tentang Pembinaan Imam; Dekrit Presbyterorum ordinis tentang Pelayanan dan Kehidupan Para Imam).

${ }^{17}$ Dekrit Inter mirifica tentang Upaya-upaya Komunikasi Sosial; Dekrit Unitatis Redintegratio tentang Ekumenisme; Dekrit Apostolicam actuositatem tentang Kerasulan Awam; Dekrit Ad gentes tentang Kegiatan Misioner Gereja; Pernyataan Gravissimum educationis tentang Pendidikan Kristen; Pernyataan Nostra aetate tentang Hubungan Gereja dengan Agama-agama Bukan Kristen; dan Pernyataan Dignitatis humanae tentang Kebebasan Beragama. 
Raidin Sinaga, Mengenang Dekrit Perfectae Caritatis ...

Gereja karena dua alasan: bahaya fariseisme dan "godaan Sinagoga". 18 Bahaya fariseisme adalah resiko yang dihadapi setiap institusi yang menjadikan sarana menjadi tujuan. Awal gerakan orang-orang Farisi memang sangat murni, baik dan mulia. Seratus enampuluh lima tahun sebelum Kristus, gerakan ini sungguh gerakan yang mempertahankan keutuhan dan kemurnian iman yudaisme melawan pengaruh hellenisme yang semakin kuat dan menimbulkan bahaya kesesatan dan penyembahan berhala. Dalam perjuangan ini banyak orang Farisi menjadi martir. Sayang bahwa pelan-pelan gerakan ini berubah menjadi sistem legal yang mematikan, bukan menghidupkan. Dalam konteks Gereja dikatakan bahwa struktur Gereja tidak lagi sebagai sarana dari Roh Kudus dan rahmat Allah tetapi menjadi tujuan. Yang terjadi adalah legalisme hukum yang sering dikecam Yesus dalam Injil, misalnya, "Hari Sabat diadakan untuk manusia dan bukan manusia untuk hari Sabat" (Mrk. 2:27); "Celakalah kamu, hai ahli-ahli Taurat dan orangorang Farisi ... (Mat. 23:13-36).

Bahaya "godaan Sinagoga", yakni ketakutan terhadap dunia dan kemajuan yang sedang berjalan. Kemajuan dianggap "jahat" dan bertentangan dengan Injil. Anggapan bahwa Gereja adalah institusi sempurna yang tidak boleh ikut perubahan dan perkembangan dunia, cukup lama sebagai keyakinan dalam sejarah Gereja Katolik. Hal ini semakin memperparah keadaan. Situasi terbalik juga ada di kalangan teolog dan umat yang menganggap kemajuan adalah bagian dari perjalanan Gereja dan semua harus diterima. Menghadapi kedua tendenis ini Congar mengingatkan: a) perubahan hanya dalam level moral tanpa menyentuh struktur akan tidak efektif; b) penginjilan tidak bisa hanya dalam level rohani tanpa mangikutsertakan hal-hal duniawi, eksterior, ekonomis, sosial, kultural dari kehidupan manusia; c) pembaharuan yang utuh dan lengkap harus dengan terjun ke dalam kemajuan dan perkembangan dunia, dengan cara ini Gereja akan "mempermandikan" dan "menyelamatkan" kemajuan tersebut.19

\section{Kebenaran Berbeda dari Ungkapannya}

Dalam dekrit Unitatis redintegratio tentang ekumenisme bapak-bapak konsili menegaskan bahwa "pembaharuan Gereja secara hakiki terdapat

18 Yves Congar, Vera e falsa riforma nella Chiesa, traduzuoni di Stefano Campana (Milano: Jaca Book, 1972), hlm. 122-150.

${ }^{19}$ Bdk. Yves Congar, Vera e falsa riforma ..., hlm. 133. 149-150. 
dalam peningkatan kesetiaan terhadap panggilannya". ${ }^{20}$ Untuk mewujudkan prinsip ini dituntut sikap yang benar dan metode yang tepat. Sikap yang benar ini dengan sangat jelas ditekankan dan dijelaskan oleh Paus Yohanes XXIII dalam pidato pembukaan Konsili Vatikan II, pada tanggal 11 Oktober 1962: “ ... ut sacrum christianae doctrinae depositum efficaciore ratione custodiatur atque proponatur ... est enim aliud ipsum depositum Fidei, seu veritates, quae veneranda doctrina nostra continetur, aliud modus, quo eaedem enuntiantur, eodem tamen sensu eademque sententia". ${ }^{21}$ Sangat perlu dibedakan antara kebenaran dan ungkapannya. Kebenaran tetaplah kebenaran, ia, dalam arti tertentu, abadi dan tetap bertahan; sedangkan ungkapannya bisa dan pastilah berubah-ubah dan berbeda-beda sesuai dengan tuntutan zaman, tetapi dengan tetap mengingat bahwa ungkapan tidak boleh mengaburkan atau meniadakan kebenaran yang mau diungkapkannya. ${ }^{22}$

Sikap ini menuntut metode pembaharuan yang setia tetapi kreatif (creative fidelity), setia terhadap kebenaran atau depositum Fidei, yakni semua yang telah dinyatakan secara pasti oleh Allah dalam dan melalui Yesus Kristus demi keselamatan manusia. Harta karun ini harus dijaga, ditafsirkan dan diwartakan dengan setia kepada semua orang sampai akhir zaman (1Tim: 6:20; 2Tim 1: 12.14).23 Untuk itu para bapak konsili sungguh melihat keharusan untuk kembali ke Sumber, yakni Sabda Allah, untuk menganalisis konteks serta membaca tanda-tanda zaman.

\section{Tujuan Pastoral24}

Keunikan Konsili Vatikan II yang membedakan dari konsili ekumene lain yang terjadi sebelumnya ialah konsili ini tidak dilatarbelakangi oleh "kekacauan atau perpecahan" dalam Gereja karena ajaran tertentu. Oleh karena itu tujuan dari Konsili Vatikan II bukan untuk mengutuk ajaranajaran sesat (anathema) atau mendefinisikan kebenaran yang "diserang",

20 UR, 6.

${ }^{21}$ Paus Yohanes XXIII, Gaudet Mater Ecclesia, dalam EV/1, nn. 45 dan 55.

22 Richard R. Sinaga, Communion of Communities..., hlm. 5.

${ }^{23}$ DV, 10; GS, 62; Lih. Gerard O'Collins - Edward G. Farrugia, Kamus Teologi, diterjemahkan oleh I. Suharyo (Yogyakarta: Kanisius, 1996), hlm. 51.

24 Poin ini mengikuti uraian Francis A. Sullivan, Creative Fidelity. Weighing and Interpreting Documents of the Magisterium (Dublin: Gill \& MacMillan, 1996), hlm.162-169. 
Raidin Sinaga, Mengenang Dekrit Perfectae Caritatis ...

atau diragukan sebagai dogma yang harus diimani semua umat Katolik. Tujuan, seperti sudah diuraikan di atas, adalah untuk pembaharuan (aggiornamento). Pembaharuan ini umumnya berciri pastoral, seperti sangat jelas diungkapkan oleh Paus Yohanes XXIII dalam pidato pembukaan Konsili Vatikan II.

Dengan konsili ini yang dilaksanakan lebih sebagai "magisterium pastoral" dari pada "magisterium doktrinal", artinya umumnya keputusan yang diambil lebih bersifat pastoral dari pada doktrinal. Lalu pertanyaan yang muncul: Bagaimanakah kwalifikasi teologis dari ajaran serta keputusan konsili? Apakah ajaran konsili yang bersifat pastoral mengikat untuk semua umat beriman? Ada perdebatan besar dalam menjawab pertanyaan ini. Yang jelas, tidak ada dogma baru yang ditetapkan dalam Konsili Vatikan II, karena itu dengan konsili ini yang dilaksanakan adalah Magisterium biasa tetapi universal. ${ }^{25}$ Dengan kata lain, walaupun tidak ada dogma baru yang ditetapkan tetapi setiap ajaran konsili mengikat semua umat beriman katolik.

\section{Dasar Teologis Pembaharuan Dekrit Perfectae caritatis}

Pembaharuan yang terjadi dalam dokumen Konsili Vatikan II tentang Hidup Bakti, harus dibaca dengan latar belakang pembaharuan eklesiologis, paham tentang dunia dan misi yang terjadi dalam Konsili ini. Hal ini mengikuti prinsip untuk memahami atau menginterpretasi dokumen-dokumen Konsili Vatikan II: kesatuan seluruh dokumen, dan

25 Dibedakan 2 modus pelaksanaan Kuasa Mengajar Resmi Gereja (Magisterium): biasa dan luar biasa. Magisterium biasa juga masih dibedakan dalam dua jenis: tidak universal (uskup secara pribadi, sekelompok uskup, dan Uskup Roma) dan universal (kolegio uskup-uskup tersebar di seluruh dunia tetapi sepakat menetapkan suatu ajaran yang definitif; kolegio uskup-uskup dalam konsili atau tersebar di seluruh dunia tetapi tidak bermaksud untuk menetapkan satu atau beberapa ajaran definitif). Magisterium luar biasa ialah uskup-uskup dalam konsili dan menetapkan ajaran definitif; atau Uskup Roma sebagai kepala kollegio para uskup [Bdk. Richard R. Gaillardetz, Teaching with Authority: A Theology of the Magisterium in the Church (Collegeville, Minnesota: A Michael Glazier Book, The Liturgical Press, 1997), hlm. 159-224; Francis A. Sullivan, Magisterium: Teaching Authority in the Catholic Church (Dublin: Gill \& MacMillan, 1983), hlm. 52-78]. 
hubungannya yang begitu erat dengan seluruh tradisi Gereja Katolik. ${ }^{26}$ Tiga pembaharuan di atas sungguh mempengaruhi pembaharuan dan penyesuaian yang terjadi dalam dekrit Perfectae caritatis, namun pembaharuan eklesiologis merupakan dasar yang paling penting.

\section{Pembaharuan Eklesiologis}

Paham para bapak konsili tentang Gereja sungguh berubah dalam dokumen-dokumen konsili Vatikan II. Perubahan ini sungguh nyata dan jelas diungkapkan dalam Konstitusi Dogmatis Lumen gentium tentang Gereja. Konsep Gereja sebelumnya sangat yuridis, hirarkis dan piramidal. Tekanan sungguh kuat pada hirarki, dan seolah-olah hirarki adalah Gereja. Hal ini masih sangat berpengaruh pada proyek awal27 dan yang kedua ${ }^{28}$ untuk skema konstitusi dogmatis tentang Gereja. Yang terutama adalah otoritas dan struktur yang berasal dari Kristus, yang lain (awam dan religius) adalah bagian yang tidak berada di pusat tapi di pinggiran. Gambaran Gereja yang paling populer ialah Societas perfecta (Komunitas/Institusi sempurna) yang sangat diwarnai sentralisme dan otoritas pusat/Roma.

${ }^{26}$ Walter Kasper memberikan empat prinsip untuk menginterpretasi dokumen konsili: 1) Teks harus dimengerti dalam hubungan dengan seluruh dokumen; 2) Kesatuan antara teks dan roh yang menjiwai seluruh dokumen; 3 ) Dokumen harus dimengerti dalam cahaya seluruh tradisi Katolik yang sehat; 4) Katolisitas adalah kesatuan antara tradisi dan interpretasi tanda-tanda zaman [Walter Kasper, Theology and Church (New York: Crossroad, 1989), hlm. 172173].

27 Skema Proyek awal adalah 1) Makna/Kodrat Gereja Militan; 2) Keanggotaan Gereja Militan dan Pentingnya Gereja untuk Keselamatan; 3) Uskup sebagai tingkat tertinggi dalam Sakramen Imamat; 4) Uskup-uskup setempat; 5) Status Kesempurnaan Injili; 6) Awam; 7) Kuasa Mengajar dalam Gereja; 8) Otoritas dan Ketaatan dalam Gereja; 9) Hubungan Gereja dan Negara; 10) Kewajiban Gereja Mewartakan Injil kepada semua bangsa di seluruh dunia; 11) Ekumenisme [Gerard Philips, La Chiesa e il suo mistero. Storia, testo e commento della Lumen Gentium (Milano: Jaka Book, 1975), hlm. 18; Herbert Vorgrimler (ed.), Commentary on the Documents of Vatican II, vol I, transl. by Lalit Adolphus, et. al. (New York: Burns Oates/Herder and Herder, 1968), hlm. 106].

28 Skema Proyek Kedua adalah 1) Misteri Gereja; 2) Struktur Hirarki Gereja, secara khusus Uskup; 3) Umat Allah, khususnya Awam; 4) Panggilan pada Kekudusan dalam Gereja (Gerard Philips, La Chiesa..., hlm. 25; Herbert Vorgrimler (ed.), Commentary on the Documents of Vatican II, vol I, ..., hlm. 110). 
Raidin Sinaga, Mengenang Dekrit Perfectae Caritatis ...

Dalam Lumen gentium yang dibicarakan bukan lagi "makna" Gereja, tetapi misterinya. Dasar keberadaannya adalah misteri keselamatan: Allah ingin menyelamatkan semua manusia, maka Ia mengutus Putra Tunggal-Nya. Gereja dilihat sebagai sakramen keselamatan universal: tanda dan sarana pewujudan rencana keselamatan Allah. Gereja tidak lagi dilihat sebagai "institut keselamatan", tetapi sebagai sakramen keselamatan. ${ }^{29}$ Keselamatan dimengerti sebagai "kesatuan umat manusia dengan Allah" dan "persatuan umat manusia". ${ }^{0}$ Maka kalau Gereja disebut sebagai Sakramen Keselamatan artinya Gereja adalah alat dan sarana kesatuan umat manusia dengan Allah dan persatuan umat manusia.

Gambaran Gereja yang digunakan sungguh biblis, terlebih dengan mengatakan Gereja sebagai Umat Allah. Dengan menggunakan konsep ini mau ditekankan bahwa Gereja dipanggil dan dipersatukan oleh Allah. Kesatuan yang dimaksudkan bukanlah pertama-tama kesatuan organisatoris tetapi kesatuan iman. Paham ini menempatkan Gereja dalam kerangka sejarah keselamatan dan menghapus konsep piramamidal Gereja, yang menempatkan hirarki di atas seluruh umat Allah. ${ }^{31}$ Hal ini sangat jelas dinyatakan oleh bapak-bapak konsili: "Satulah umat Allah terpilih, samalah martabat para anggotanya".32 Maka tidak ada lagi hirarki di atas anggota yang lain.

Pembaharuan eklesiologis Konsili Vatikan II dapat diterangkan dengan lebih baik bila Gereja dimengerti dalam perspektif persekutuan (koinonia). Memang, Konsili, bahkan Perjanjian Baru, tidak pernah secara langsung menggambarkan Gereja sebagai Persekutuan, namun konsep persekutuan dilihat sebagai kata kunci dan benang merah seluruh pembaharuan dalam Konsili. Dengan konsep inilah, menurut J. Ratzinger, Konsili menerangkan inti, kebaharuan serta keaslian ajarannya tentang Gereja. ${ }^{33}$ Asalnya adalah persekutuan cinta Trinitaris, Bapa-Putera-Roh Kudus, yang memberikan Diri dalam Putera dan diwujudkan dalam Roh Kudus. Dalam konsep persekutuan (koinonia) dirangkumkan pelbagai dimensi Gereja: panggilan-jawaban, kesatuan,

${ }^{29}$ Tom Jacobs, Gereja menurut Vatikan II (Yogyakarta: Kanisius, 1987), hlm. 17.

${ }^{30}$ LG, 1 dan 9.

${ }^{31}$ Tom Jacobs, Gereja..., hlm. 24.

${ }^{32} \mathrm{LG}, 32$.

${ }_{33}$ J. Ratzinger, Church, Ecumenism and Politics, transl. by Robert Nowell (Midlegreen, Slough: St. Paul Publications, 1988), hlm. 7. 
hidup bersama, memberi dan ambil bagian, tanggungjawab bersama, persaudaraan. Di dalamnya terkandung unsur misteri dan yang kelihatan. Persekutuan ini hidup dari mendengar Sabda dan merayakan Ekaristi. Oleh karena itu Gereja disebut sebagai Persekutuan Ekaristik. ${ }^{34}$

\section{Paham Tentang Gereja dan Dunia}

Tom Jacobs menyimpulkan 'bahwa 'Lumen Gentium' harus dibaca ke arah konstitusi pastoral tentang Gereja di dalam dunia dewasa ini". ${ }^{35}$ Kesimpulan ini menunjukkan perubahan penilaian Gereja terhadap dunia dalam Konsili Vatikan II. Gereja tidak lagi dilihat sebagai suatu institusi yang berada di luar dunia, sebaliknya, Gereja ada dalam dan untuk dunia tetapi 'berasal' dari Allah; atau lebih tepat dikatakan didirikan oleh Allah. Untuk menerangkan misteri ini Konsili pertama-tama menggambarkan Gereja sebagai Tubuh Mistik Kristus. ${ }^{36}$ Kristus mengumpulkan orang-orang dari segala bangsa, dan secara gaib menjadikan mereka menjadi Tubuh-Nya dengan mengaruniakan RohNya. Dalam Tubuh ini Kristus menjadi Kepala yang mencurahkan hidup-Nya untuk semua anggota-anggotanya.

Kemudian konsili melanjutkan dengan menggambarkan Gereja yang kelihatan dan sekaligus rohani. Gereja kudus sebagai persekutuan iman, harap dan cinta kasih itu dilihat sebagai himpunan yang kelihatan, Gereja di dunia, tetapi sekaligus juga sebagai persekutuan rohani yang diperkaya dengan kurnia-kurnia surgawi. Dengan mengikuti pandangan Paus Pius XII yang terdapat dalam ensiklik Mystici Corporis (1943) dan Humani generis (1950), konsili menyatakan bahwa dalam Gereja ada perpaduan kompleks antara unsur manusiawi dan ilahi. Kesatuan ini dianalogikan dengan misteri inkarnasi: "Sebab seperti kodrat yang dikenakan oleh Sabda ilahi melayani-Nya sebagai upaya keselamatan yang hidup, satu dengan-Nya dan tak terceraikan dari pada-Nya, begitu pula himpunan sosial Gereja melayani Roh Kristus, yang menghidupkannya demi pertumbuhan Tubuhnya (lih. Ef. $4: 16)^{\prime \prime} \cdot{ }^{37}$

34 J. Ratzinger, Church ..., hlm. 7-11; LG, 2-8; J.-M.R. Tillard, Church of Churches. The Ecclesiology of Communion, transl. By R.C. De Peaux (Collegeville, Minnesota: A Michael Glazier Book, The Liturgical Press, 19920, hlm. xi.

35 Tom Jacobs, Gereja..., hlm. 33.

${ }^{36} \mathrm{LG}, 7$.

37 LG, 8. 
Raidin Sinaga, Mengenang Dekrit Perfectae Caritatis ...

Dunia, yang selalu dilihat dalam hubungan dengan manusia, dilihat sangat positif. Gereja tidak berada di samping dunia; Gereja dan dunia adalah satu, yakni manusia dalam dua aspek relasinya dengan Allah. Aspek pertama, manusia disebut "dunia" dalam arti sebagai subyek yang otonom ${ }^{38}$ berhadapan dengan Allah. Aspek kedua, manusia adalah "Gereja" dalam arti sebagai "subyek" yang mewujudkan relasi dengan Allah dalam agama dan sakramen-sakramen Gereja. Maka, kalau berbicara tentang dialog antara Gereja dan dunia, sama artinya dengan mengatakan dialog antara manusia sendiri sebagai subyek yang otonom dan sebagai anggota Gereja. Dalam konteks ini menjadi sangat penting melihat fungsi Gereja: sejauh mana Gereja berusaha untuk membantu manusia untuk berkembang menjadi manusia seutuhnya, baik sebagai pribadi yang otonom, maupun dalam relasinya dengan Allah? Identitas Gereja dalam hal ini bukanlah dengan mati-matian mempertahankan bentuk tertentu atau berusaha menyatu dengan sistim yang ada dalam masyarakat, melainkan dalam relevansi dan ekspressinya yang otentik. 39

\section{Paham Tentang Gereja dan Misito}

Pembaharuan Konsili Vatikan II tentang Gereja dalam hubungannya dengan misi dapat dirangkumkan dengan cara ini: Konsili telah menempatkan kembali misi pada tempatnya yang sesungguhnya, yakni menjadi jantung Gereja (in medio Ecclesiae). Hal ini sangat jelas dan tegas dinyatakan konsili dalam dekrit Ad gentes tentang Kegiatan Misioner Gereja: “Pada hakekatnya Gereja peziarah bersifat misioner, sebab berasal dari perutusan Putera dan perutusan Roh Kudus menurut rencana Allah Bapa". ${ }^{41}$ Dengan demikian dinyatakan bahwa misi adalah sungguh tugas pertama dan terutama Gereja dan misi sendiri dilihat sebagai alasan keberadaannya (raison d'etre).

Gereja ada untuk misi perutusan, yakni demi keselamatan manusia dan dunia. Dari terminologi Yunani yang digunakan untuk menggambarkan Gereja, fungsi utama atau untuk apa Gereja ada menjadi sangat jelas. Kata yang dipakai ialah ekklesia (ek-kaleo) yang berarti "dipanggil keluar untuk berkumpul". Panggilan ini bertujuan

\footnotetext{
38 GS, 36.

39 Tom Jacobs, Gereja..., hlm. 34-35.

40 Topik ini dirangkumkan dari Raidin R. Sinaga, Church and Mission...,
} hlm. 30-35, dan Richard R. Sinaga, Communion of Communities..., hlm. 12-15.

41 AG, 2. 
bukan demi Gereja sendiri tetapi demi misi perutusan. Gereja ada bukan untuk dirinya sendiri tetapi demi pelayanan umat manusia dan untuk membawa kabar keselamatan bagi seluruh dunia.

Begitu lama dalam pemahaman Gereja ada pemisahan antara Gereja dan misi. Gereja ada di Eropah yang mengutus misionaris ke daerah misi. Misi dimengerti dalam arti geografis. Konsekwensinya ialah hanya sebagian orang yang dipanggil dan bertanggungjawab untuk misi. Misi sendiri tujuannya ialah mentobatkan orang dan mendirikan Gereja. Dengan Konsili Vatikan II paham ini berubah. Hanya ada satu misi yang "bersumber pada hakekat Gereja sendiri". ${ }^{42}$ Walaupun tetap berlaku "misi ad gentes", tetapi dimana-mana sekarang bisa disebut "daerah misi". Sesudah Konsili Vatikan II, penanggungjawab misi juga tidak lagi terbatas untuk orang-orang tertentu, tetapi semua orang berdasarkan baptisan. Tujuan misi bukan lagi terutama pendirian Gereja lokal, tetapi keselamatan integral: "keselamatan vertikal dan horizontal", menyangkut jiwa dan badan, dalam hubungan seseorang dengan Allah dan dengan sesama manusia. 43

\section{Level Otoritas, Gaya Bahasa dan Struktur Dekrit}

Roh pembaharuan dan dasar teologis yang sudah dibicarakan di atas merupakan "latar belakang umum" untuk memahami dekrit Perfectae caritatis. Disebut "latar belakang umum" karena berlaku untuk semua dokumen Konsili Vatikan II. Yang akan dibicarakan di bawah ini adalah "latar belakang khusus" untuk memahami lebih dalam dekrit tentang pembaharuan dan penyesuaian hidup bakti .

\section{Level Otoritas ${ }^{44}$}

Ada enambelas dokumen Konsili Vatikan II yang terbagi atas empat konstitusi, semblilan dekrit dan tiga pernyataan. Konstitusi sendiri terbagi tiga: dua dogmatis (Dei Verbum, dan Lumen gentium), satu pastoral (Gaudium et spes), dan satu tanpa atribut (Sacrosanctum concilium). ${ }^{45}$ Bapa-bapa Konsili tidak pernah memberi keterangan

42 AG, 6.

${ }^{43}$ Bdk. David J. Bosh, Transforming Mission. Paradigm Shifts in Theology of Mission (Maryknoll, New York: Orbis Book, 1993), hlm. 393-400.

${ }^{44}$ Francis A. Sullivan, Creative Fidelity..., hlm. 169-171.

${ }^{45}$ Lih. Ctk, 2 
Raidin Sinaga, Mengenang Dekrit Perfectae Caritatis ...

tentang arti perbedaan itu, terutama dalam hubungannya dengan level otoritas yang terkandung dalam dokumen sendiri. Namun peristiwa yang terjadi dalam Konsili, menurut Francis A. Sullivan, jelas menunjukkan bahwa perbedaan tersebut sungguh berarti.

Satu saat, ketika revisi dari skema Lumen gentium dibagikan kepada para uskup untuk dibahas dan didiskusikan kembali, mayoritas anggota Komisi Teologis sangat terkejut melihat bahwa dalam teks yang dibagikan judul bukan Konstitusi dogmatis tetapi Konstitusi saja, yakni Konstitusi tentang Gereja. Dalam pertemuan berikut mereka menuntut supaya atribut itu dicantumkan kembali. Apa artinya? Bukan karena ada dogma yang baru yang dirumuskan, tetapi mau menyatakan level otoritas yang dikandung oleh dokumen tersebut berbeda dari dokumen yang lain. Namun, menurut Sullivan, orang harus berhati-hati untuk tidak salah mengerti bahwa hanya dalam kedua konstitusi dogmatis tersebutlah Konsili berbicara secara otoritatif. Sebab dalam materi iman dan kesusilaan, Konsili dengan sendirinya mengajarkannya secara berwibawa (otoritatif). Maka, sangatlah perlu membaca maksud Konsili (mind of the council). Maksud konsili ini, menurut Komisi Teologis, bisa diketahui hanya dengan memahami bahasa yang digunakan "sesuai dengan norma-norma interpretasi teologis". Untuk itu sangat dianjurkan untuk membaca tigapuluh volume Acta Synodalia Sacrosancti Concilii Eocumenici Vaticani Secundi.

Menurut "kelas"-nya, Perfectae caritatis adalah "kelas dua" dalam pengelompokan dokumen-dokumen Konsili Vatikan II karena disebut dekrit, keputusan dan bukan konstitusi ("level 1") atau pernyataan ("level 3"). Secara umum, konsitutusi dimengerti sebagai "aturan atau undang-undang dasar". Dekrit atau keputusan, dan pernyataan harus didasarkan pada undang-undang dasar tersebut. Dalam pelaksanaan ajaran Konsili arah ini cukup ditekankan, namun harus tetap diingat bahwa dalam kasus-per-kasus tertentu setiap dokumen juga bisa memuat otoritas yang tinggi, tergantung, menurut Ratzinger, bagaimana proses sampai kepada keputusan tersebut ("intensive discussion that led to the decisions" $) .46$

\section{Gaya Bahasa dan Struktur Dekrit}

Sudah sejak abad ke-19 Gereja, dalam diri Hirarki dan dokumendokumen yang dikeluarkan, sangat bernada yuridis dalam pembicaraan

${ }^{46}$ Francis A. Sullivan, Creative Fidelity..., hlm. 170. 
dan konsep tentang hidup religius. Yang diberikan umumnya adalah definisi, norma-norma dan aturan-aturan yang harus ditaati, juga sanksi bagi mereka yang menentang ketetapan yang diberikan Gereja. Kalau kita membaca dekrit Perfectae caritatis hal itu cukup jelas kelihatan. ${ }^{47} \mathrm{Hal}$ ini memang sungguh diinginkan oleh utusan dari Kongregasi untuk LHB: dekrit harus berisikan problem-problem yuridis mengenai LHB karena pendasaran teologis sudah diberikan dalam Konstitusi Dogmatis Lumen gentium_bab VI. Dengan demikian sudah sejak awal ada persoalan: pemisahan teologi dari disiplin, spiritualitas dari hukum, semangat Injili dari standard yang diungkupkan dalam aturan-aturan atau norma-norma. ${ }^{48} \mathrm{Hal}$ ini mau tak mau pasti akan mewarnai pemahaman Gereja tentang Lembaga Hidup Bakti.

Dekrit terdiri dari 25 nomor yang diawali dengan satu nomor untuk pendahuluan dan satu nomor untuk penutup. Sesudah pendahuluan (n. 1), dilanjutkan dengan azas-azas pembaharuan yang sesuai, dan norma-norma praktis pembaharuan yang disesuaikan, serta pelaksana pembaharuan (nn.2-4). Lalu menyusul unsur-unsur umum pada pelbagai bentuk hidup religius dan pentingnya hidup rohani (nn. 5-6). Kemudian dilanjutkan dengan typologi hidup religius: tarekat kontemplatif, tarekat kerasulan, monastik konventual, kaum awam, dan serikat sekular (nn. 7-11). Dibahas juga secara khusus tentang kaul-kaul religius (nn. 12-14), tentang hidup bersama (n. 15), tentang klausura para rubiah (n. 16), busana religius (n. 17), pembinaan anggota (n. 18), pendirian tarekat baru (n. 19), melestarikan, menyesuaikan atau meninggalkan karya-karya khusus tarekat (n. 20), tarekat atau biara yang mengalami kemerosotan (n. 21), federasi tarekat religius (n. 22), konferensi para pemimpin (n. 23), panggilan religius (n. 24), dan penutup (n. 25).

\section{Pembaharuan dan Penyesuaian Hidup Bakti dalam dekrit Perfectae caritatis}

\section{Pembaharuan dan Penyesuaian}

Dalam dekrit dirumuskan dengan jelas apa yang dimaksud dengan pembaharuan dan penyesuaian. Pembaharuan (renovatio) ialah

47 Bdk. Friedrich Wulf, "Decree on the Appropriate Renewal of the Religius Life", in Herbert Vorgrimler (ed.), Commentary on the Documents of Vatican II, vol II ..., hlm. 302-303. 354.

${ }^{48}$ Friedrich Wulf, "Decree on...", hlm. 333-334. 
Raidin Sinaga, Mengenang Dekrit Perfectae Caritatis ...

"pengacuan terus-menerus kepada sumber-sumber seluruh hidup kristiani serta inspirasi tarekat-tarekat yang mula-mula"; sedangkan penyesuaian dilihat dalam hubungan "dengan kenyataan zaman yang sudah berubah". ${ }^{49}$ Pembaharuan tidak hanya sekedar kembali ke maksud pendiri, tidak hanya sekedar pengintensifan yang bersifat rohani dan asketis. Pembaharuan menyangkut "terus menerus kembali ke " sumber-sumber seluruh hidup kristiani, yakni Kitab Suci dan tradisi rohani yang agung dari Gereja Katolik. Dikatakan "terus menerus kembali" (continuus reditus) karena pemahaman kita tentang kebenaran dalam Kitab Suci dan tradisi tetap berkembang dengan menggunakan metode analisis dan interpretasi yang baru. Penyesuaian dituntut supaya semangat pendiri tidak tinggal menjadi huruf-huruf yang mati; perlu terus menerus disesuaian dengan tanda-tanda zaman. Penyesuaian ini tidak hanya menyentuh aspek eksternal saja, atau hanya sekedar memodifikasi, tetapi menyangkut hal yang lebih dalam yang menuntut tindakan kreatif atas dasar pemahaman, pengalaman, dan visi yang luas dan mendalam. ${ }^{50}$

Pembaharuan dan penyesuaian tidak bisa dipisahkan satu dengan yang lain karena keduanya saling mengandaikan dan terkait satu dengan yang lain. Dalam diskusi waktu konsili ada kecenderungan memisahkan keduanya: pembaharuan dilihat sebagai kewajiban semua anggota komunitas, sedangkan penyesuaian menjadi tanggungjawab pemimpin. Bahaya dari sikap ini ialah pembaharuan akan dilihat secara eksklusif sebagai pembaharuan religius dalam arti kembali menghidupi semangat pendiri, sementara penyesuaian terbatas hanya pada hal-hal eksterior. 51

\section{Azas-azas Pembaharuan ${ }^{52}$}

Dekrit memberikan lima azas pembaharuan:

a) Mengikuti Kristus menurut Injil sebagai pedoman tertinggi. Hal ini dilihat perlu oleh Konsili karena begitu sering terjadi pendangkalan visi dalam pelbagai anggaran dasar dan peraturan dari komunitas zaman ini, atau sebaliknya terlalu moralistik dan asketis.

\footnotetext{
49 PC, 2.

50 Friedrich Wulf, “Decree on...”, hlm. 336.

51 Friedrich Wulf, “Decree on...”, hlm. 333.

52 Friedrich Wulf, "Decree on...", hlm. 336-339.
} 
b) Mengakui dan memelihara dengan setia semangat para Pendiri dan maksud-maksud mereka yang khas serta tradisi-tradisi yang sehat. Di sini berlaku prinsip "creative fidelity" - kesetiaan yang kreatif. Pinsip ini juga berlaku untuk tarekat-tarekat baru tetapi mengikuti semangat pendiri tarekat yang sudah ada.

c) Ikut serta dalam kehidupan Gereja. Setiap tarekat harus tetap menjaga koinonia - persekutuan dan sensus ecclesiae - serasa dan sepikiran dengan Gereja. Tarekat ada tidak terutama untuk dirinya sendiri tetapi demi kemuliaan Allah dalam Gereja.

d) Mendidik anggota-anggota tentang paham yang benar mengenai kenyataan orang-orang pada zaman sekarang dan kebutuhan Gereja, supaya mampu membaca tanda-tanda zaman dan memberikan bantuan yang tepat guna. Prinsip ini ditegaskan untuk menyadarkan tarekattarekat yang "fuga mundi", bahwa pengabdian kepada Allah dilaksanakan dalam pelayanan kepada sesama. Prinsip ini juga perlu untuk tarekat yang aktif dalam kerasulan, supaya lebih memerhatikan efektifitas pelayanannya.

e) Pentingnya pembaharuan rohani (renovatione spirituali). Hal ini dilihat sebagai prasyarat untuk suksesnya pembaharuan dan penyesuaian. Hal ini tidak hanya sekedar kemauan yang kuat, atau menyangkut spiritualitas secara umum atau kesetiaan pada kaul-kaul. Pembaharuan rohani ini berarti setiap anggota komunitas/tarekat dan seluruh komunitas dijiwai oleh semangat yang baru, yang bersumber dari jati diri yang paling dalam.

Namun demikian, diingatkan bahwa pembaharuan lebih diharapkan terwujud bukan dengan penambahan hukum dan aturan melainkan dari "penghayatan pedoman-pedoman serta konstitusi yang lebih saksama". 53

\section{Pelaku Pembaharuan}

Dengan sangat tegas Dekrit menyatakan bahwa keberhasilan pembaharuan dan penyesuaian hanya dapat dicapai dan berjalan dengan tepat melalui kerjasama semua anggota tarekat. ${ }^{54}$ Unsur

$$
\begin{aligned}
& { }^{53} \text { PC, } 4 d . \\
& { }^{54} \text { PC, } 4 a .
\end{aligned}
$$


Raidin Sinaga, Mengenang Dekrit Perfectae Caritatis ...

demokratis dalam tarekat religius dituntut oleh Dekrit. ${ }^{55}$ Dasarnya pada pembaharuan eklesiologis, Gereja sebagai Persekutuan (koinonia) di mana semua anggotanya memiliki kesamaan fundamental. Hal ini juga sesuai dengan tuntutan kemajuan dan zaman.

Tidak sedikit Bapa-bapa Konsili mengutarakan kekhwatiran mereka akan bahaya matinya kaul ketaatan yang sangat hakiki untuk Hidup Bakti karena terlalu besar kebebasan pribadi dari setiap anggota. Ketakutan ini dijawab Dekrit dengan menyatakan bahwa tugas para pimpinanlah untuk menentukan kaidah-kaidah pembaharuan, menetapkan hukum-hukumnya, dan membuka ruang bagi pengalaman yang memadai dan bijaksana. Tetapi supaya "suara anggota" tetap dijamin dan tidak terjadi sikap otoriter, ditambahkan modus: "yang menyangkut keadaan seluruh tarekat, dengan cara yang tepat" pemimpin "meminta nasehat para anggota dan mendengarkan mereka". ${ }^{56}$

\section{Beberapa Topik Pembaharuan}

\section{Status Hidup Bakti dalam Struktur Gereja}

Tidak bisa diragukan peran penting Hidup Bakti dalam sejarah dan perkembangan Gereja Katolik. Hal ini juga diakui dalam Konsili Vatikan II. Tidak seorang pun juga mempertanyakan tempat yang sah dari Hidup Bakti dalam Gereja. Dengan kata lain, status gerejawi mereka tidak pernah dipersoalkan. Yang menjadi persoalan ialah tempat yang tepat Hidup Bakti dalam struktur Lumen gentium dan bagaimana porsi yang cocok untuk membahas Hidup Bakti ini. ${ }^{57}$ Persoalan lain ialah bagaimana hubungan Hidup Bakti ini dengan klerus dan awam.

Belum pernah dalam sejarah Gereja Hidup Bakti dibicarakan dengan serius dan sistematik, seperti dalam Konsili Vatikan II.58 Pembicaraan ini tentu dilatarbelakangi oleh pembaharuan eklesiologis, di mana Gereja dilihat sebagai Umat Allah yang terdiri dari hirarki,

${ }^{55}$ Friedrich Wulf, “Decree on...", hlm. 342.

$56 \mathrm{PC}, 4 \mathrm{~b}$.

${ }^{57}$ Gerard Philips, La Chiesa e il suo mistero..., hlm. 437.

58 Manuel Ruiz Jurado, "Consecrated Life and the Charisms of the Founders", dalam Rene Latourelle, Vatican II Assessment and Perspectives. Twenty-five Years After (1962-1987), vol. III (New York/Mahwah: Paulist Press, 1989), hlm. 6. 
awam dan Hidup Bakti. Awalnya susunannya adalah hirarki, Hidup Bakti, dan awam. Susunan ini dilatarbelakangi paham lama tentang keluhuran dan martabat ketiga kelompok ini yang berasal dari Allah, dan juga karena 'hidup dekat' dengan Allah. Tetapi susunan ini kemudian diganti oleh Komisi Kordinatoris menjadi hirarki, awam dan Hidup Bakti. Alasannya adalah permintaan "dari bawah" selama diskusi dalam Konsili untuk lebih menekankan betapa penting peran awam dalam Gereja dan misi apostolik mereka di tengah dunia. ${ }^{59}$ "Ketiga kelompok" dibahas satu per satu dalam Konsili seperti didokumenkan dalam Lumen gentium.

Tema tentang Panggilan Umum kepada Kekudusan termasuk juga dalam skema Lumen gentium. Dasarnya ialah semua anggota Umat Allah dipanggil kepada kesempurnaan sebagaimana dinyatakan oleh Yesus kepada murid-murid-Nya: "Kamu harus sempurna, seperti Bapamu yang di sorga sempurna adanya" (Mat. 5: 48). Soal: Apakah cocok skema: Hirarki - Awam - Hidup Bakti - Penggilan Umum Kepada Kekudusan? Bagaimana hubungan antara panggilan umum kepada kekudusan ini dengan Hidup Bakti? Bukankah Hidup Bakti merupakan ungkapan khusus dari Panggilan Umum Kepada Kekudusan? Ada usul untuk menyatukan saja kedua topik tersebut. Sementara yang lain menganggap hal itu akan mengurangi atau malah menghilangkan pentingnya status Hidup Bakti untuk Gereja. Maka diputuskan untuk membahas Hidup Bakti sesudah panggilan umum kepada kekudusan. ${ }^{60}$

Walaupun dalam Lumen gentium sudah ada pembicaraan khusus tentang Hidup Bakti yang dilihat dalam kaitannya dengan Panggilan Umum kepada kekudusan, namun masih ada dekrit yang secara khusus berbicara tentang Hidup Bakti. Dalam dekrit ini, walaupun masih diberi dasar teologis, tetapi yang dibicarakan adalah hal-hal praktis-yuridis seputar pembaharuan dan penyesuaian Hidup Bakti, karena dasar teologis sudah diberikan dalam Lumen gentium.

Persoalan lain yang diperjelas dalam Konsili adalah hubungan antara hirarki-Hidup Bakti-awam. Sebelum Konsili Vatikan II cukup

59 Friederich Wulf, "Introductory Remarks on Chapter V and VI", dalam Herbert Vorgrimler (ed.), Commentary on the Documents of Vatican II, vol I, ..., hlm. 253.

${ }^{60}$ Bdk. Gerard Philips, La Chiesa e il suo mistero..., hlm. 437-438; Manuel Ruiz Jurado, "Consecrated Life...", hlm. 5-9. 
Raidin Sinaga, Mengenang Dekrit Perfectae Caritatis ...

kuat pendapat yang mengatakan bahwa Hidup Bakti adalah "status antara" klerus dan laikus. Hidup Bakti adalah "status antara" karena bukan klerus atau hirarki dan bukan awam. ${ }^{61}$ Dalam Konsili Vatikan II Hidup Bakti tidak dilihat sebagai "status antara" klerus dan laikus, karena anggota Hidup Bakti terdiri dari klerus dan awam. Status sebagai klerus atau awam didasarkan pada institusi ilahi, sementara panggilan hidup sebagai anggota Hidup Bakti dilihat sebagai kharisma. ${ }^{62}$

\section{Dari Status Perfectionis ke Vita Consecrata}

Cukup lama dalam Gereja Katolik cara hidup religius diyakini sebagai "pola hidup sempurna" dengan status sempurna. Keyakinan ini didasarkan pada pemahaman akan teks-teks Kitab Suci: “Tetapi carilah dahulu Kerajaan Allah dan kebenarannya, maka semuanya itu akan ditambahkan kepadamu" (Mat. 6: 33) dan "”...haruslah kamu sempurna, sama seperti Bapamu yang di sorga adalah sempurna" (Mat. 5: 48). Maka orang mulai dan semakin intensif menghidupi prinsip soli Dei vacari: ada hanya untuk Allah saja dan tetap hidup dalam kehadiranNya. Prinsip ini didukung oleh teks biblis dan filsafat Plotinus yang dualisme. Dalam Kitab Mazmur dikatakan: "Vacate et videte, quoniam Ego sum Dominus" (Mzm. 46: 11, "Diamlah dan ketahuilah, bahwa Akulah Allah"). Teks ini digabungkan dengan Surat Rasul Paulus kepada Jemaat di Korintus: “... ut vacatis oratione” (1Kor 7: 5, “... supaya kamu mempunyai kesempatan untuk berdoa").63

Plotinus mengajarkan untuk menggapai yang transenden saja dan berusaha untuk mengatasi gangguan-gangguan dari hal-hal materiil. Walaupun prinsip ini tidak murni mewarnai hidup para rahib, tetapi sangat nyata dari pola hidup mereka: menggapai yang ideal dengan meninggalkan keduniawian ("fuga mundi") dan hidup hanya bersama dengan Allah dalam doa dan kontemplasi. Akibatnya, mereka

61 Paus Pius XII menyatakan kepada peserta kongres para religius tahun 1950: "Il diritto divino ha deciso che il clero (clerici) si distingua dai laici. Fra i due gradi si colloca lo stato di vita religiosi...". Dikutip dari Gerard Philips, La Chiesa e il suo mistero..., hlm. 438.

62 Gerard Philips, "Dogmatic Constitution on the Church. History of the Constitution", dalam Herbert Vorgrimler (ed.), Commentary on the Documents of Vatican II, vol I, ..., hlm. 123; bdk. Gerard Philips, La Chiesa e il suo mistero..., hlm. 438 .

${ }^{63}$ Bdk. Friedrich Wulf, “Decree on...”, hlm. 350. 
tidak perduli dengan sesama dan keselamatan mereka, juga sangat kurang perhatian pada tugas Gereja untuk menyelamatkan dan menyempurnakan dunia. Hidup hanya untuk Allah dianggap adalah hidup yang sebenarnya atau sekurang-kurangnya yang paling baik dan sempurna. Maka, semakin terpisah dari dunia (a mundo secessus) diyakini sebagai semakin sempurna. ${ }^{64}$

Dalam Konsili Vatikan II, perbedaan dan kekhasan para religius tidak lagi dilihat pada "status perfectionis" tetapi pada pentakdisan/pembaktian (consecratio). Dibedakan dua macam pentakdisan/pembaktian: sakramental (Imamat, Perkawinan, Krisma, dan Baptisan) dan non-sakramental (kaul, janji).65 Yang pertama, pembaktian terjadi melalui tindakan sakramental, sedangkan yang kedua melalui pengikraran dan pelaksanaan kaul-kaul religius dan nasehat-nasehat Injil. Melalui pembaktian ini seseorang disucikan dan seluruh hidup diabdikan demi kemuliaan dan pelayanan Allah, Gereja dan sesama.

Perbedaan utama antara status perfectionis dan vita consecrata terletak pada realisasi konkrit pencapaian tujuan utama ("mencari Allah satu-satunya dan di atas segalanya" - soli Dei vivant atau soli Dei vacare)66, dan inisiatif untuk cara hidup tersebut. Dalam status perfectionis seseorang tidak perduli pada kepentingan dan keselamatan sesama, tidak terlibat dalam tugas perutusan Gereja. "Tembok" pemisah dibangun yang memisahkan seseorang dari dunia dan malah "dari Gereja" demi hidup hanya untuk Allah. Inisiatif berasal dari pribadi yang ingin menempuh cara hidup ini. Untuk vita consecrata inisiatif berasal dari Allah: "atas dorongan Roh Kudus", dan mengikuti atau menjawab "panggilan Allah"67 Karena alasan ini dengan tegas Konsili mengatakan bahwa pedoman tertinggi untuk pembaharuan Hidup Bakti ialah "mengikuti Kristus menurut Injil". ${ }^{8}$ Tujuan dari Hidup Bakti adalah ibadah dan pelayanan: pujian kepada Allah dalam ibadat dan dalam pelayanan kepada sesama, serta ikut serta dalam misi keselamatan Gereja.

${ }^{64}$ Bdk. Friedrich Wulf, “Decree on...”, hlm. 351.

65 Tentang topik-topik yang dibicarakan kami ambil dan rangkumkan dari artikel Antonio Queralt, "The Value of 'Religius' Consecration According to Vatican II", dalam Rene Latourelle, Vatican II... vol III, hlm. 27-63.

${ }^{66} \mathrm{PC}, 5$.

$67 \mathrm{SC}, 1$.

68 SC, 2. 
Raidin Sinaga, Mengenang Dekrit Perfectae Caritatis ...

Pembaktian Melalui Nasehat-nasehat Injil69

Pembaktian melalui nasehat-nasehat Injil adalah pembaktian non-sakramental. Dengan menghidupi nasehat-nasehat Injil, teristimewa melalui kaul-kaul religius, setiap anggota Lembaga Hidup Bakti memperoleh rahmat kekudusan. Dekrit Perfecta caritatis menyebutkan lima alasan mengapa pengikraran kaul-kaul dan penghayatannya diyakini sebagai pembaktian atau pentakdisan: a) merupakan jawaban akan panggilan Allah; b) berakar dalam penakdisan baptis; c) mengungkapkan penyerahan diri kepada Allah; d) diterima oleh Gereja; e) merupakan komitmen untuk mengabdi kepada Gereja. ${ }^{70}$

Apa yang menjadi ciri khas pembaktian non-sakramental ini, yang membedakannya dari pembaktian sakramental? Salah satu perbedaannya ialah "pengingkaran dunia". Hal itu tidak terjadi pada pembaktian melalui Sakramen Baptis, Krisma, dslb. Ciri khas yang lain adalah pembaktian melalui nasehat-nasehat Injil ini dilihat sebagai "tanda". Hal itu sangat jelas diungkapkan dalam Konstitusi Dogmatis Lumen gentium, di mana diberikan sebagian besar landasan doktriner untuk dekrit Perfecta caritatis ${ }^{71}$ : “... pengikraran nasehat-nasehat Injil merupakan tanda, yang dapat dan harus menarik secara efektif semua anggota Gereja, untuk menunaikan tugas-tugas panggilan kristiani dengan tekun". Pengikraran kaul-kaul dilihat sebagai tanda hidup yang akan datang, yakni hidup baru dan kekal yang diperoleh berkat penebusan Kristus. Dengan membebaskan diri dari keprihatinankeprihatinan duniawi, anggota Hidup Bakti memperlihatkan kepada semua orang beriman harta sorgawi yang telah hadir dan nanti akan disempurnakan di Surga. Status ini secara istimewa menampilkan keunggulan Kerajaan Allah, dan memperlihatkan keagungan Kristus Sang Raja dan daya Roh Kudus yang tak terbatas. ${ }^{72}$

Ciri khas yang lain adalah "menjadi korban". Dengan mengikuti Kristus dan corak hidup yang dijalani-Nya, para anggota Lembaga Hidup Bakti harus siap untuk menjalani hidup yang bercirikan cinta dan pengorbanan secara lebih intensif. Dengan cara itulah mereka secara

69 Bdk. Jean Beyer, "Life Consecrated by the Evangelical Counsels", dalam Rene Latourelle, Vatican II... vol III, hlm.64-89.

70 PC, 5.

71 Landasan doktriner untuk pembaharuan dan penyesuaian Hidup Bakti ada pada LG, 43-47 dan PC, 1-3.

72 LG, 44. 
lebih erat disucikan untuk mengabdi Allah. Dengan mengikrarkan ketiga kaul anggota Lembaga Hidup Bakti dilihat sebagai korban yang berkenan kepada Allah. Mereka "menjadi korban" dengan pengikraran kaul ketaatan, kemiskinan dan kemurnian. ${ }^{73}$

\section{Karisma Pendiri dan Karisma Institusi}

Tidak di satu tempat pun dalam dokumen Konsili Vatikan II, kata karisma dipasangakan dengan pendiri tarekat. Pasangan kata ini muncul kemudian dalam dokumen sesudah Konsili Vatikan II. ${ }^{74}$ Dekrit Perfectae caritatis_menggunakan ungkapan "semangat para Pendiri"..$^{75}$ Semangat Pendiri ini dilihat sebagai "pengalaman Roh". Pengalaman ini kemudian diwariskan kepada para pengikut yang memelihara, mendalami, dan mengembangkannya sesuai dengan tuntutan zaman. Semangat Pendiri ini menjadi titik tolak untuk keotentikan sebuah tarekat.

Karisma Pendiri yang telah dikembangkan sesuai dengan tuntutan zaman menjadi karisma tarekat. Karisma ini, dengan demikian, sangat dinamis tetapi rohnya tetap sama. Dalam karisma institusi ini nampak kekhasan setiap tarekat. Kekhasan ini akan mewarnai cara hidup menuju kesucian dan kerasulan tarekat. Kekhasan ini menjadi identitas untuk setiap tarekat. "Oleh karena itu Gereja melindungi dan memajukan corak khas pelbagai tarekat religius" ${ }^{76}$

\section{Penutup}

Pengikraran kaul-kaul adalah inti Hidup Bakti. Meminjam ungkapan kaum Reformator, hal itu dianggap sebagai "articulus stantis et cadentis vitae consecratae", norma dengannya bisa kita lihat apakah Hidup Bakti itu masih sehat atau sudah sakit-sakitan. Disamping keberhasilan menghidupinya, pasti Lembaga Hidup Bakti juga "mengalami kasus ketidak-konsistenan", seperti kata Paus Fransiskus

73 Antonio Queralt, "Values of...", hlm. 43-48. Yang mengamalkan nasehat-nasehat Injil bukanlah hanya para religius, tetapi juga serikat-serikat sekular. Maka, judul dekrit Perfectae caritatis adalah kurang tepat karena menyebut "Pembaharuan dan Penyesuaian Hidup Religius". Seharusnya ialah "Pembaharuan dan Penyesuaian Hidup Bakti".

${ }^{74}$ Misalnya, EN, 11 dan MR, 11.

$75 \mathrm{PC}, 2$.

${ }^{76} \mathrm{LG}, 44$. 
Raidin Sinaga, Mengenang Dekrit Perfectae Caritatis ...

dalam Surat Apostolik kepada Semua Pelaku Hidup Bakti dalam Rangka Tahun Hidup Bakti. ${ }^{77}$ Keberhasilan akan "menambah kesucian" Gereja, sementara ketidak-konsistenan akan membuat Gereja bercacat. Kesimpulan ini sungguh masuk akal karena meskipun Hidup Bakti "tidak termasuk dalam susunan hirarkis Gereja, namun tidak dapat diceraikan dari kehidupan dan kesucian Gereja".78 Kredibilitas kesaksian Gereja dipertaruhkan dengan pengamalan kaul-kaul yang dijanjikan oleh anggota-anggota Lembaga Hidup Bakti tersebut.

Sudah terjadi dalam sejarah skandal-skandal sehubungan dengan ketiga kaul religius. Memaklumi skandal entah dengan alasan apapun bukanlah jalan yang baik, karena hal itu akan merongrong atau sekurang-kurangnya mengurangi kepercayaan orang lain terhadap Gereja. Oleh karena itu, marilah memperbaiki diri. Untuk tujuan ini saya mengajak kita untuk merefleksikan tentang kaul kemiskinan. Selama ini tekanan diberi seolah-olah hanya pada kemiskinan pribadi/individual; kurang perhatian terhadap kemiskinan komuniter. Konsili Vatikan II meminta supaya hal ini tidak diabaikan dengan mengatakan: "Dengan mengindahkan keanekaan situasi setempat, tarekat-tarekat sendiri hendaknya berusaha memberi kesaksian bersama tentang kemiskinan" ${ }^{79}$ Bagaimana kita melihat tarekat-tarekat di KAM telah memberi kesaksian bersama tentang kemiskinan? Apakah tidak ada kesan bahwa tarekat-tarekat tersebut mewah mencari keuntungan yang berlebihan dan menumpuk harta kekayaan?

Suatu ketika, dua orang suster dari salah satu Tarekat Religius di Afrika, bingung mendengar jawaban dan sikap dari seorang ibu pengemis. Kedua suster ini keluar dari gerbang biara yang megah dengan pakaian bersih. Ibu pengemis tersebut sangat berharap akan memperoleh uang dari suster yang berpenampilan "mewah" tersebut. Alangkah terkejut dan kesal ibu itu mendengar jawaban suster yang jujur tetapi tidak masuk akal: "Maaf bu, kami tidak punya uang!" Ibu itu berkata: "Apa? Tidak punya uang? Bagaimana mungkin dua gadis yang keluar dari rumah besar dan mewah, memiliki beberapa mobil dan yayasan tidak punya uang?" Sejak saat itu, ibu itu tidak lagi percaya kepada suster yang menurut dia sangat kaya tetapi tidak perduli dengan orang-orang kecil dan miskin.

$$
====0000====
$$

\footnotetext{
${ }^{77}$ Lihat pada artikel no. 1.

78 LG, 44.

79 PC, 13.
} 


\section{DAFTAR PUSTAKA}

E. Martasudjita, Ekaristi: Tinjauan Teologis, Liturgis, dan Pastoral (Yogyakarta: Kanisius, 2005), hlm. 233.

Xavier Rynne, Vatican Council..., hlm. 8. Lode L. Wostyn, professor teologi di Maryhill School of Theology, Claretian Publications, 1990), hlm. 44.

Raidin R. Sinaga, Church and Mission..., hlm. 68-69.1 GS, 4.

Johannes Feiner, “Commentary...”, hlm. 96.

Dokumen Konsili Vatikan II, diterjemahkan oleh R. Hardawiryana (Jakarta: Dokumentasi dan Penerangan KWI, 1993), hlm. vi.

Richard R. Sinaga, Communion of Communities: Cara Baru Hidup Menggereja di Asia (Nagahuta-Pematangsiantar: Rumah Pembinaan Fransisikan, 2008), hlm. 6.

Yves Congar, Vera e falsa riforma nella Chiesa, traduzuoni di Stefano Campana (Milano: Jaca Book, 1972).

Paus Yohanes XXIII, Gaudet Mater Ecclesia, dalam EV/1, nn. 45 dan 55.

Walter Kasper, Theology and Church (New York: Crossroad, 1989, hlm. 172-173.

Tom Jacobs, Gereja menurut Vatikan II (Yogyakarta: Kanisius, 1987), hlm. 17.

J. Ratzinger, Church, Ecumenism and Politics, transl. by Robert Nowell (Midlegreen, Slough: St. Paul Publications, 1988), hlm. 7.

David J. Bosh, Transforming Mission. Paradigm Shifts in Theology of Mission (Maryknoll, New York: Orbis Book, 1993), hlm. 393-400.

Friedrich Wulf, "Decree on the Appropriate Renewal of the Religius Life", in Herbert Vorgrimler (ed.), Commentary on the Documents of Vatican II, vol II ..., hlm. 302-303. 354.

Manuel Ruiz Jurado, "Consecrated Life and the Charisms of the Founders", dalam Rene Latourelle, Vatican II Assessment and Perspectives. Twenty-five Years After (1962-1987), vol. III (New York/Mahwah: Paulist Press, 1989), hlm. 6.

Gerard Philips, La Chiesa e il suo mistero..., hlm. 437-438; Manuel Ruiz Jurado, "Consecrated Life...", hlm. 5-9. 
Raidin Sinaga, Mengenang Dekrit Perfectae Caritatis ...

Jean Beyer, "Life Consecrated by the Evangelical Counsels", dalam Rene Latourelle, Vatican II... vol III, hlm.64-89.

Antonio Queralt, “Values of...", hlm. 43-48. 